Ankara Üniversitesi Türk Inkılâp Tarihi Enstitüsü Atatürk Yolu Dergisi

S 25-26, Mayı-Kasim 2000 s. 181-200

\title{
Cemiyet-i Akvam'a Müzaheret Cemiyeti-Türkiye'de Kuruluşu ve Prag Konferansı
}

\author{
Yrd.Doç.Dr.Serpil SÜRMELİ
}

ÖZET

Cemiyet-i Akvam kurulması fikri ortaya atıldı ̆̆ı günden itibaren Avrupa'nın her tarafinda bu cemiyeti desteklemek üzere cemiyetler teşkil edilmeye başland.

Cemiyet-i Akvam'a Müzaheret Cemiyeti adını taşıyan bu kuruluşların tesisindeki maksat, Cemiyet-i Akvam'a dahil olan milletleri cemiyetin kararlarını desteklemek üzere aynı amaç etrafında toplamak, dünyanın her tarafinda bu yönde propagandalar yapmak, her ülkede kurulmuş müzaheret cemiyetlerinin uyum içerisinde çalışmalarını sağlamak, cemiyeti gücün değil, hukukun hakim kılınacă̆ı bir cemiyet haline getirmek ve Cemiyet-i Akvam'a dahil olmayan milletlerin de bu kuruluş içinde yer almalarını sağlamaktı. Bu ortak amaçlar etrafında bir araya gelen her cemiyet aynı zamanda kendi ülke menfaatlerini milletlerarası platformlarda korumak ve savunmakla görevliydi.

Türkiye'de Cemiyet-i Akvam'a Müzareheret Cemiyeti'nin kuruluşu ise, Sakarya Savaşı'nın kazanılmasının ardından ve bu zaferin yankılarının sürdüğ̈̈ bir dönemde gerçekleşti. Cemiyet, Ankara'nın Anadolu'ya yakınlığıyla bilinen Tevfik Paşa ve hükümetine verdiği emir üzerine İstanbul'da kuruldu. 7 Aralık 1921'de kuruluşuna karar verilen cemiyetin teşekkül tarihi ise 27 Nisan 1922 idi. Çoğunluğu Darü'lfünûn müderrislerinin girişimleriyle oluşan cemiyetin kurucu ve üyelerinin sayısı 25 kişi idi.

Cemiyetin kuruluşunda milli görev olarak yer alan önemli madde, Türk varlığını ve istiklalinin tammını Misak-ı Milli esasları doğrultusunda sağlamak ve savunmaktı.

Türk Müzaheret Cemiyeti, Cemiyet-i Akvam'a Müzaheret Cemiyetlerinin Milletlerarası Birliği'nin merkezi Brüksel'de bulunan Umumi Katipliği'ne. 1922 Mayıs ayı ortalarında başvurarak, bu birliğe katılma talebinde bulundu. Bu talebi

• Atatürk Üniversitesi, İletişim Fakültesi Gazetecilik Bölümü Öğretim Üyesi 
olumlu karşılanan Türk Müzaheret Cemiyeti 4-7 Haziran 1922 tarihlerinde Prag'da altıncısı düzenlenecek olan konferansa davet edildi.

Türkiye'yi Prag'da Ahmed İhsan (Tokgöz), Cemil (Bilsel) ve Menemenlizade Edhem Beylerden oluşan bir heyet temsil etti. Konferansta öncelikle birliğe katılmak isteyen ülkelerin kabul başvuruları görüşülecekti. Ancak Türk Heyeti, Yunan heyetinin birliğe kabul edilmemesi yönünde büyük bir muhalefetiyle karşılaştı. Yunanlılar, konferansta bulunan ülke heyetlerini her firsatta yapılması alışkanlık haline getirilen mezalim hikayeleriyle etkilemek için yoğun çaba harcadılar.

Gerek Türkiye ve Türkleri yakından tanıyan ülke temsilcilerinin yaptıkları konuşmalar, gerekse Türk heyetinin delilleriyle ortaya koyduğu gerçekler, Yunan heyetinin çabasını boşa çıkarttı. Türk Müzaheret Cemiyeti birliğe kabul edildiğ $i$ gibi, Türk milli davası da milletlerarası bir platformda tüm açıklı̆̆ı ve haklılığıyla gözler önüne serildi.

Anahtar Kelimeler: Cemiyet-i Akvam, Cemiyet-i Akvam'a Müzaheret Cemiyetleri Milletlerarası Birliği, Türkiye Müzaheret Cemiyeti, Altıncı Prag Konferansi.

\section{ABSTRACT}

Since the idea of foundation of League of Nations was put forward, the committes was come to organise in order to support this committe in everyplace of Europe. The purpose of the foundation of these organizations called as in the support committe of League of Nations was together the nations involving in League of Natons together in order to support the decision, to make propagande in every where of the world, to provide a harmonic work of Support Committes founded in every place of the world, to form a committe in which the law was predominant instead of the power, to provide the other nations to take the place in this organization.

The foundation of the comitte of League of Nations in Turkey realized after the winning of Sakarya War and the reflections of this victory. The committe was founded in İstanbul due to the order of Ankara to the government of Tevfik Pasha known his closeness to the Anatolia. The foundation date of the comitte which was taken the foundation decision on $7^{\text {th }}$ December 1921 was $27^{\text {th }}$ April 1922. The committe which was formed by most University professors was founded by total 25 people.

The most important article taking the place as a national duty in the fondation of the committe was to provide and defend the Turkish existence and independence in the direction of National Pact principles.

Turkish Support Committe applied for the general secretary, the centre of International Union of Committe of League of Nations was in Brussell, in the middle of May of 1922. This demand was accepted positively, and Turkish Support 
Committe of International Committe was invited to the congress which would be held in Prag 4-7 June 1922.

A delegation forming Ahmed İhsan (Tokgöz) and Cemil (Bilsel) and Menemenlizade Edhem Bey represantived Turkey in Prag. At the conference, it would be viewed first the applications of the countries which would like to participate in the community. But, Turkish delegation encountened a great opposition of Greek delegation relating to not to admit the Turkish delegation to the union. The Greeks spent intensive efforts to influce members of other country's delegations about the words of tyranny stories. Both the speeches by Turks and members of countries in conference, and the realites existed by the evidences by Turkish delegation proved Greek delegations to be unjustice. As well as admission to the union of Turkish support Committe to League of Nations, Turkish National Matter was brought into the eyes with all prutiy and fairness in an international platform.

Key words: League of Nation, International Union of the Support Comitte to the League of Nations, The Turkish Support Committe, The VI ${ }^{\text {h }}$ Prag Conference.

\section{GİRIŞ}

I.Dünya Savaşı'yla ortaya çıkan korkunç yıkım ve dünyaya yansıyan görüntüler, insanlık adına büyük bir uyarıcı etki yarattı. Bu durum başta Amerika Birleşik Devletleri ve Fransa olmak üzere bir kısım devletlerin barışçı özlemlerini arttırdı ve dünya barışı için ileriye yönelik adımlar atılması yolunda harekete geçirdi. Bu harekette birinci derecede rol oynayan ülke ise Amerika Birleşik Devletleri oldu.

A.B.D. Başkanı Woodrow Wilson, 8 Ocak 1918 tarihinde verdiği demeçle, barışa duyulan özlem içinde ve dünya barışı yolunda ilk önemli adımı atan kişi oldu. Wilson bu demecinde, devletlerin siyasi bağımsızlığının ve toprak bütünlüğünün güvence altına alınmasını ve bu amaç doğrultusunda çalışılması için de Cemiyet-i Akvam adını taşıyan bir teşkilatın kurulmasını istemekteydi. Bu görüşü destekleyen ve devletlerin kendi kaderlerini kendilerinin tayin etmesini savunan İngilizler bu amaca hizmet eden bir tasarı hazırladılar. Bu tasarı I. Dünya Savaşı sonunda toplanan barışa hazırlık konferansında oylamaya sunuldu ve 28 Nisan 1919' da da oybirliğiyle kabul edildi. Arkasından aynı tarihli Versailles Antlaşması ve diğer antlaşmaların başına konan bu tasarıyla Cemiyet-i Akvam'ın kuruluşu gerçekleşmiş oldu. Ancak cemiyetin kuruluşu, Versailles Antlaşması'nın yürürlüğe girdiği 10 Ocak 1920 tarihiyle resmiyet kazandı. Merkezi de tarafsız bir ülke olan İsviçre'nin Cenevre şehri olarak tayin edildi ${ }^{1}$.

' Türk Ansiklopedisi, C.XXIV, M.E.B., Ankara, 1976, s.166; Büyük Larousse Sözlük ve Ansiklopedisi, 16.Cilt, Milliyet Gazetecilik A.Ş. İstanbul, 1986, s.8180. 
Tabii bu arada Cemiyet-i Akvam fikri ortaya atıldığı günden itibaren Avrupa'nın her tarafında Cemiyet-i Akvam'a Müzaheret Cemiyeti ${ }^{2}$ ad $_{ı}$ altında cemiyetler kurulmaya başlandı. Bu cemiyetlerin kurulmasındaki maksat, Cemiyet-i Akvam’a dahil olan milletleri cemiyetin kararlarını desteklemek için aynı amaç etrafında toplamak, dünyanın her tarafında bu hususta propagandalar yapmak ve her memlekette kurulmuş olan müzaheret cemiyetlerinin birlikte uyum içerisinde çalışmalarını temin etmekti. Aynı zamanda Cemiyet-i Akvam'ı ideal amaçlarını gerçekleştirebilecek bir hale getirerek, cemiyete dahil olmayan milletlerin de bu kuruluşun içinde yer almalarını sağlamaktı ${ }^{3}$.

\section{Cemiyet-i Akvam'a Müzaheret Cemiyeti’nin Türkiye'de Kuruluşu Amaç ve Görevleri}

Cemiyet-i Akvam'a Müzaheret Cemiyeti'nin Türkiye'de kurulmasına ise, Sakarya Savaşı'nın kazanılmasının ardından ve bu zaferin yankılarının sürdüğü bir dönemde, Anadolu'ya yakınlığıyla bilinen Tevfik Paşa ve hükümeti tarafından karar verilmiş, bu kararın alınması da cemiyetin İstanbul'da kurulmasını isteyen Ankara'nın verdiği emir ${ }^{4}$ üzerine olmuştur. Tevfik Paşa hükümeti, yakında Prag'da Cemiyet-i Akvam'a hizmet eden cemiyetler birliğinin toplanacağını, burada Türkiye'nin düşmanları tarafından aleyhine sağlanacak sözlerin red ve tekzibini sağlamak üzere bir veya iki delegenin kesinlikle bulunması gereğini ve milli bir Türk Cemiyeti'nin kurularak bu toplantıya katılmasına dair Bern Sefareti'nden gönderilen resmi mektubu ve buna ek olarak Hariciye Nezareti'nin 27 Kasım 1921 tarihli resmi yazısını görüşerek, Cemiyet-i Akvam'a Müzaheret Cemiyeti'nin Darü'l-fünun müderrisleriyle, mevcut cemiyetlerin irfan ve kültür sahibi üyelerinden oluşturulmasına, Prag'a gönderilecek delegelerin de bunlar arasından ve gerekli vasıflara sahip kişilerden seçilmesine 7 Aralık 1921 tarihinde verdiği kararla kabul edilmişti ${ }^{5}$.

Hükümet kararında olduğu gibi, Darü'l-fünûn müderrislerinden Aynizade Hasan Tahsin, Muslihiddin Adil, Cemil ve Hayreddin Beylerle, Ayandan Çürüksulu Mahmud Paşa ile Doktor Besim Ömer Paşa 1922 yılı Ocak ayından itibaren Cemiyet-i Akvam'a Müzaheret heyetini kurmak için girişimde bulunmuşlar ve bir komisyon oluşturarak görüşmelere başlamışlardı.

Aynizade Hasan Tahsin Bey Cemiyet-i Akvam'a Müzaheret Heyeti ve çalışmaları hakkında 1 Şubat 1922 tarihinde İkdam gazetesi muhabiriyle bir görüşme yapmıştı. Hasan Tahsin Bey bu görüşmede Cemiyet-i Akvam'a müzaheret adıyla diğer ülkelerde olduğu gibi Türkiye'de de bir cemiyet kurulacağını, önceden isimleri basınca da malum olan şahısların Darü'l-fünun'da bir komisyon halinde

${ }^{2}$ Milletler Cemiyeti'ni Destekleme Cemiyeti.

3 Vakit, 1 Mayis 1338/1922, No:1577; Mehmed Cemil-Menemenlizade Edhem, Cem'iyet-i Akvam'a Müzaheret Cem'iyeti'nin Beyne'l-milel İttihadı, Altıncı Pag Konferansı'na Aid Rapor (4-7 Haziran 1922), İstanbul, 1338, s.1.

${ }^{4}$ Ahmet İhsan (Tokgöz), "Montreux Konferansı 1922-1933” Uyanış Servet-i Fünun, 7410.Cilt, No:1926-241 (13 Temmuz 1933), İstanbul, s.98.

${ }^{5}$ Meclis-i Vükelâ Mazbatası, Dosya No:222, Vesika No: 179. 
birçok kez toplandığını, cemiyetin nizamnamesinin hazırlandığını, bir iki güne kadar hükümete takdim edip cemiyetin kuruluş iznini alacaklarını ifade etmiş ve nizamnamenin önemli noktalarını aşağıdaki şekilde açıklamıştı:

“1-Cem'iyet-i Akvam projesinde bazı ta'dilât icrası ki ta'dilat şimdiye kadar muhtelif ilmi kongrelerde en sonra da "Torn" ictima'iyat kongresinde uzun uzadiya mevzu'bahs olmuş ve birçok esasat kabul edilmişti.

“2-Düşmanlarımız tarafından 'aleyhimizde işa'a edilen müftereyatı tashih. Bu da gerek risalelerle ve gerek konferanslarla vesair münasib görülecek tarz ve şekilde olacaktır.

"3-Misak-1 Milli esasatı dairesinde Türk varlığının ve istiklâl-i tammının te'mini için hükümetin siyasetine müzaheret.

“4-Cem'iyet-i Akvam'a esas olacak olan ve ihtilafat-1 düveliyenin sulhan tesviyesini istihdaf eden efkâr-1 milliyenin beyne'l-milel neşr ve ta'mimi.

"Şüphesiz bütün bu makasıdın kuvveden fi'ile ihracı için bazı vesaite ihtiyaç hasıl olacak bu vesait de tabi’i neşriyat ve matbu'at encümenleri gibi a'zadan alınacak 'aidat-1 şehriye ile cem'iyete efrad-1 ahalinin suret-i iştirakiyle, meclis idaresiyle, meclis-i 'umuminin suret-i teşekkülü ile taht-1 te'mine alınabilir.

"Nizamnâmede her cem'iyet nizamnamesinde mevcud olan ahkam münderictir. Bu ahkam kısmen İsviçre'nin nizamnamesinden alınmış ve memleketimize göre icrası muktezi ta'dilat yapılmıştır. Yalnız cem'iyete idhal ve cem'iyetten ihrac olunacak a'za hakkındaki mevadd tesbit edilmemiştir. Bu henüz müzakere edilmektedir ve yakında bu da ta'ayyün edecektir.

"Prag'da Nisan ayı zarfında "Beyne'l-milel Müzaheret Cem'iyetleri" toplanacaktır ${ }^{6}$ Bizim cem'iyetimiz teşekkül ettikten sonra hey'et-i 'umumiyeyi kongreye da'vet edecek ve icra edilecek intihab neticesinde gönderilebilecek a'za tefrik edilecektir." Ayrıca gazete "İstihbaratımıza nazaran Cem'iyet-i Akvam Müzaheret Hey'eti mü'essisleri meyanında bi'l-ahire bazı zevat-1 muhtereme de dahil olmuştur. Bunlar arasında güzide hanımefendiler de mevcuddur. 'Ayan'dan Abdurrahman Şeref, müderrislerden Mustafa Zühdü, Nusret Beylerle, Mişon Efendi ve Müze Müdürü Halil Beyler şimdi mü’essisin meyanındadır. Prenses İffet Hanımefendi ile Ahmed Rıza Bey'in hemşireleri Selma Hanım "Cemiyet-i Akvam'a Müzaheret Hey'eti" müessisini meyanında dahil olmuşlardır."’ şeklinde cemiyet kurucuları arasında yer alacak isimleri de açıklamaktaydı.

Cemiyet-i Akvam'a Müzaheret Komisyonu Aynizade Hasan Tahsin Bey’in de belirttiği gibi nizamnamenin cemiyete üye kabulü ve ihracı ile ilgili maddelerini de tamamladıktan sonra Şubat ayı içinde Cemiyet-i Akvam'a Müzaheret Cemiyeti

\footnotetext{
${ }^{6}$ Cemiyet-i Akvam'a Müzaheret Cemiyeti'nin Prag Konferansı 4-7 Haziran 1922 tarihleri arasında yapılmıştır.

${ }^{7}$ İkdam, 2 Şubat 1338/1922, No:8939.
} 
Nizamnamesi, teşekkül eden cemiyet tarafından Dahiliye Nezareti’ne ${ }^{8}$ sunuldu. Bu nizamname cemiyetin unvan ve gayesi, teşkilat, aza, umur-1 maliye, mevadd-1 müteferrika, madde-i muvakkata ve müessisler olmak üzere 7 başlık altında maddeleştirilmişti ${ }^{9}$.

27 Nisan 1922 tarihinde resmen kuruluşu gerçekleşen cemiyetin kurucu ve yöneticileri şu kişilerden oluşmaktaydi ${ }^{10}$ :

“1- A’yândan, Eski Nazır Çüruksulu Mahmud Paşa: Reis

2- Darü'l-fünûn Emini Doktor Besim Ömer Paşa: Birinci Reis Vekili

3-Darü'l-fünûn Hukuk Medresesi Reisi, Eski Müsteşar Hasan Tahsin Bey: İkinci Reis Vekili

4-Darü'l-fünûn İdare Hukuku Müderrisi Eski Müsteşar Muslihiddin Adil (Taylan) Bey: Katib-i umumi

5-Eski Hariciye Evrak-1 Umum Müdürü Hayreddin Nedim Bey: Muhasib-i mesul

6-Darü'l-fünûn Müderrisi: Ebu'l-‘ula (Mardin) Bey

7-Darü'l-fünûn Müderrisi: Cemil (Bilsel) Bey

8-Ahmed İhsan (Tokgöz) Bey

9-İsmail Hakkı (Baltacıoğlu) Bey

10-Ahmed Reşid Bey

11-Edhem (Menemencioğlu) Bey

12-Cavid Bey

13-Cemal Bey

14-Hamdi Bey

15-Reşid Saffet (Atabinen) Bey

16-Zühtü (İnhan) Bey

17-Selma Hanım

${ }^{8}$ Vakit, 1 Mayis 1338/1922, No:1577.

${ }^{9}$ Cem'iyet-i Akvam'a Müzaheret Cem'iyeti Nizamnamesi, İstanbul, 1338, s.3-8.

${ }^{10}$ Cemil (Bilsel) Cem'iyet-i Akvam'a Müzaheret Cem'iyeti, İstanbul, 1339, s.43; Cem'iyet-i Akvam'a Müzaheret Cem'iyeti Nizamnamesi, s.8; Vakit, 1 Mayıs 1338/1922, No:1577; Tarık Zafer Tunaya, Türkiye'de Siyasal Partiler; Mütareke Dönemi (19181922), C.II, Genişletilmiş İkinci Baskı, Hürriyet Vakfı Yayınları, İstanbul, 1986, s.625. 
18-Sa'adeddin Bey

19-Suphi Ziya Bey

20-Doktor Akil Muhtar Bey

21-Abdurrahman Şeref Bey

22-Mehmed Ali Tevfik Bey

23-Nezihe Hanım

24-Nusret Bey

25-Yakup Kadri (Karaosmanoğlu) Bey"

Cemiyet-i Akvam'a Müzaheret Cemiyeti'nin kurucu üyelerinden biri olan Devletlerarası Hukuk Müderrisi Cemil Bey, cemiyetin kuruluş amacını unvanından da anlaşılacağı üzere Cemiyet-i Akvam'ın çalışmalarını desteklemek için teşekkül ettiğini ifade etmekte ve Cemiyet-i Akvam'ın kurulmasının nedenlerini şu sözlerle dile getirmekteydi:

“Bu cem'iyet beyne'l-milel iştirak-i mesa'inin inkişafı ve milletlere sulh ve müsalemet fikirlerinin te'mini için teşkil edilmişti. Fazilet-i siyasiyenin sevk-i tabi'i ve ihtiras-1 beşere teveffukuna istinad eden bütün nazariyat ve kavaidin Cihan Harbi'nde yıkıldığını gören beşeriyet bu harbden büyük bir intibah ile fenalığa her vakitten fazla nefret hissiyle çıkmıştı. Bu büyük harbde dökülen kanlar, akıtılan gözyaşları, sızlayan ve kanayan yaralar, harbde ölenler ve 'alil dönenler, yakılan ve yıkılan yerler, milletler için yeni bir yola teveccüh etmek lazım geldiğini anlatan çok kudretli 'amillerdi. Bu te'sirler altındadır ki, devletler harbe müraca' at etmemek üzere bazı ta'ahhüdatta bulunmak, 'adl ve namus üzerine mü'esses-i beyne'l-milel münasebatta 'aleniyet dairesinde hareket etmek, mu'ahedat ahkamına harfiyen ri'ayet eylemek ve milletlerin yekdiğeriyle münasebetlerinde 'adlin hükümran olmasına çalışmak vücubuna kail bulunuyorlardı" "॥. Yine Cemil Bey ve Menemenlizade Edhem Bey'in Cemiyet-i Akvam'a Müzaheret Cemiyetleri İttihadı ve 6.Prag Konferansı'na ait hazırlamış oldukları raporda Cemiyet-i Akvam'ın yeni bir kuruluş olarak bütün eksikliklerine rağmen çok büyük bir ilerleme kaydettiğini, istiklal ve hakimiyetlerini serbestçe elde etme hususunda hırslı olan devletlere ortak gayeler uğrunda birlikte çalışmayı kabul ettirebilmek ve devletlerin hakimiyetlerinin üstünde hukukun hakim olmasını sağlayabilmenin milletlerarası hayatta çok zor fakat önemli bir adım olduğunu, bu adımın güç ve eksik atıldığını bu nedenden ötürü Cemiyet-i Akvam'ın dünya çapında bir kuruluş olmadığını hatta milletlerarası ilişkilerde kendisinden beklenen nüfuz ve etkiyi gösteremediğini belirtmekteydi. Ancak bu kuruluşu yaşatmak isteyen milletlerin üzerine düşen görevi yaptığını kaydeden raporda, "Bir taraftan Cem'iyet-i Akvam'1 1slah ve ikmal etmek, mukarreratını icraya kadar zinüfuz ve mü'essir bir hale getirmek, ona mefkurevi gayelerini istihsal edebileceği bir mahiyet vermek, diğer taraftan da insaniyeti

\footnotetext{
"Cemil, Cem'iyet-i Akvam'a Müzaheret Cem'iyeti, s.1-2.
} 
mesaib-i atiyeden sıyanet için onun medar-1 istinadı olan fikirleri neşr ve tervic etmek her millet menfa'atini bu cihetleri te'mine çalışmakta görüyor. Bu sebepledir ki, mütarekeyi müte'akib her memlekette bu maksadı istihsal için cem'iyetler te'essüs etti ve evvelce müte'essis ve sulh cem'iyetleri de bunlara inkılâb veya onlarla teşrik-i mesa'i eyledi.

“Her memleket dahilinde sarfedilen bu yoldaki mesa'i esasen beyne'l-milel bir gayeye müteveccih olduğu için bi’t-tabii’ bir devlet hududunun içinde mahsur kalamazdı. İlk def'a Paris'te, sonra Londra'da üçüncü def'a olarak Brüksel'de yapılan beyne'l-mu'telifin cem'iyetler ictima'ı, bugünkü beyne'l-milel ittihadı vüicuda getirdi. Zaten müzahir cem'iyetleri her memlekette te'sis eden eazımın beyne'l-milel bir mevki'i vardı; İttihad suhuletle beyne'l-milel ve cihanşûmul bir mahiyet aldı. Merkezini ve kitabet-i 'umumisini Brüksel'de te'sis etti. Nizamnamesine nazaran İttihad 'uzuvları bir hey'et-i idare ile bir meclis ve bir hey'et-i 'umumiyeden ibarettir. Her memleketin a'zası ne kadar olursa olsun beş re'yi vardır. Karar ekseriyet-i ara ile ittihaz olunur." ${ }^{2}$ şeklinde Cemiyet-i Akvam'1 yaşatmak çabasında olan milletlerin çalışmalarını, bu cemiyeti desteklemek için Avrupa'da kurulan cemiyetlerin ne zaman ve ne şekilde oluştuğunu, teşekkül eden destekleme cemiyetlerinin bir araya gelip milletlerarası bir birlik kurmalarını ve bu birliğin çalışma organları hakkında bilgi verilmekteydi.

Cemiyet-i Akvam'ı desteklemek amacıyla bir araya gelen milletlerarası destekleme cemiyetlerinin oluşturdukları bu birlik içinde yer alan her cemiyet, milletlerarası sahada yapacakları görev kadar, kendi milli sahasında da ülke ve millet menfaatlerini oluşturdukları bu birlik platformunda korumakla görevliydi.

27 Nisan 1922'de resmen teşekkül eden Türk Müzaheret Cemiyeti'nin de milli görevi, Aynizade Hasan Tahsin Bey'in 1 Şubat 1922 tarihinde İkdam muhabiriyle yaptığı görüşmede açıkladığı gibi Misak-1 Milli esasları doğrultusunda Türk varlığının ve tam bağımsızlığının sağlanması için çalışmaktı ve bu esas cemiyetin nizamnamesinde şu şekilde belirtilmişti:

"Cem'iyetin Milli Sahadaki Vazifesi

"Evvela: Dinen ve 'ırken ve emelen müttehid ve yekdiğerine karşı hürmet-i mütekabile ve fedakarlık hisleriyle meşbu' ve hukuk-1 'ırkiye ve ictima'iyeleriyle şerait-i muhitelerine tamamen ri'ayetkâr Osmanlı İslam ekseriyetiyle meskun bulunan aksam-1 vatanın hey'at-1 mecmu'ası hakikaten veya hükmen hiçbir sebeple tefrik kabul etmez bir kûl olduğunu müdafa'a eylemek,

"Saniyen: Hukuk-1 düvel kava'id-i 'umumiyesine ve hakimiyet mefhumuyla kabil-i te'lif olmak i’tibariyle Cem'iyet-i Akvam'ın 'umdelerine mugayireti aşikar bulunan ta'ahhüdattan ma'ada bi'l-'umum ta'ahhüdat ahkamına hürmet ve ri'ayet eylemek,

12 Mehmed Cemil-Menemenlizade Edhem, Cem'iyet-i Akvam'a Müzaheret Cem'iyeti'nin Beyne'l-milel.., s.1-2. 
“Salisen: Bu esaslar dairesinde hukuk-1 milliyenin müdafa'asında hükümete ve Cem'iyet-i Akvam'daki mümessillerimize zahir olmak."13

Türk Müzaheret Cemiyeti, nizamnamesinde de görüldüğü gibi, Anadolu'nun Misak-1 Milli esasları üzerinde Türkiye'nin tam bağımsızlığı ve milli varlığını sağlamak ve korumak amacıyla yürüttüğü Milli Mücadele'nin ruhuna uygun milli bir görev anlayışına sahip olarak Milletlerarası Müzaheret Cemiyetleri Birliği içinde takip edeceği siyaseti tesbit etmiş durumdaydı. Ancak Türk Müzaheret Cemiyeti kuvvet yerine hukukun üstün kılınması temelleri üzerine oturtulmaya çalışılan ve bunun için uğraş veren milletler gibi, bu yüksek ve ideal düşünceyi desteklemek için kurulurken, Türkiye'yi parçalayarak milli varlığını hiçe sayan Cemiyet-i Akvam içindeki devletlere karşı hak ve hukuk mücadelesi veren bir milletin, yine bu devletlerin de temsilcilerinin bulunduğu müzaheret cemiyetlerinin milletlerarası platformunda temsilcisi olmak gibi bir tezatla da karşı karşıyaydı.

Cemiyet-i Akvam içinde Türkiye'ye karşı haksız saldırıları Cemil Bey şu sözlerle dile getirmekteydi:

"Lakin memleketimiz ve mevcudiyetimiz en çirkin ve haksız bir tecavüze uğrarken, en mukaddes haklarımız bu cem'iyetin maksad-1 te'sisi olan bütun 'ulvî esaslarla beraber en hissiz kimseleri bile müteneffir edecek bir surette ihlal edilirken, cem'iyetin bütün cihana müteveccih olan kürsü-i hitabetinde biraz da bizim ihmalimiz yüzünden- bitaraf ve hatta resmi hakikat ile sübut bulmuş fezayih hakkında tek bir kelime-i takbih söylenmemiş bil-akis tecavüzler tazammun eden iftiralarla dolu beyanat vaki’ olmuştu.

“Henüz girmediğimiz bize karşı vaz’iyetini bu mahiyette gördüğümüz bir Cem'iyet-i Akvam'a müzaheret bizzat kendi menafi'imize muhalif olurdu. Bu sebeple tevzih etmek mecburiyetindeyiz ki biz sırf bu mü'esses olan Cem'iyet-i Akvam'a değil, ona asıl medar-ı vücud olan ve Akvam'a yarının sa'adet yollarını açacağında şüphe bulunmayan 'ulvi esaslanına ve bu esaslara müstenid mefkurevi Cem'iyet-i Akvam'a müzaheret için cem'iyetimizi teşkil ettik. Mevcud Cem'iyet-i Akvam'ın o mahiyette inkılâb etmesine çalışmak, olanı olması lazım gelen hale koymak, hakkımızın nasibini orada tatmin etmek ve şu kadar ki, Cem'iyet-i Akvam bu hale gelinceye kadar ihmal edilebilecek bir te'sis olmadığından onun sahasında ve kezalik mümasil teşkilat karşısında beyne'l-milel ictima'alarda, bütün 'ilim sahasında haklarımızı ve varlığımızı müdafa'a etmek. İşte asıl sebeb-i te'sisimiz budur." 14

Cemil Bey Batı yazarlarının pek çoğunun Türkiye'nin haksız gösterildiği birçok meselede aslında haklı olduğunu kabul ettiklerini belirterek bu nedenle Türkiye ile ilgili herhangi bir meselenin ilmi bir heyet huzurunda layıkıyla anlatılıp izah edilebilmesi halinde Türkiye aleyhindeki siyasete ait pek çok noktanın

${ }^{13}$ Cem'iyet-i Akvam'a Müzaheret Cem'iyeti Nizamnamesi, s.4; Cemil, Cem'iyet-i Akvam'a Müzaheret Cem'iyeti, s.3-4;Tunaya, Türkiye'de Siyasal Partiler, C.II, s.627628.

${ }^{14}$ Cemil, Cem'iyet-i Akvam'a Müzaheret Cem'iyeti, s.2. 
değişebileceğini ve bunun gibi toplantılarda hazır bulunmanın Türkiye'nin yararına olduğunu ifade etmekteydi. Türkiye'nin esas ilgilenmesi gerektiği şeyin olumsuz yönler olduğunu söyleyen Cemil Bey, milletlerarası toplantılara katılan her ülkenin Darü'l-fünûnlarına, siyasi ve idari heyetlerine mensup değerli ve büyük insanlarının takip ettikleri yüksek ve iyi fikirleri yaymak için çeşitli ülkelerin çeşitli şehirlerini seçtiklerini ve her sene ayrı bir yerde toplandıklarını, bu toplantılara bütün matbuat ve ülkenin ilgi gösterdiğini, Türklerin milletleri birbirine tanıtan ve yaklaştıran bu toplantılarda bulunmamasının Türk kültürü, Türk davası ve Türk milleti adına çok büyük bir zarar olduğunu vurgulamaktaydı. Ancak zararın bundan ibaret kalmadığını belirten Cemil Bey, Türkiye'nin düşmanları tarafından aleyhine kurulmuş bir yalan ve iftira şebekesi, olduğunu, bu toplantılarda bilhassa faaliyet gösterip, orada bulunanları önceden kararlaştırdıkları gibi Türkiye aleyhine çok zararlı telkinlerde bulunarak, kararlar aldırdıklarını ifade etmekteydi. Bunlara fırsat vermeyerek Türkiye aleyhine söylenecekleri reddetmenin Milli Mücadele'nin ihmali mümkün olmayan kısmını teşkil ettiğini vurgulayan Cemil Bey, Medeniyet savaşının bugün artık yalnız silahla yapılmadığını, en kuvvetli bir milletin dahi hukukunu korumak için, silahlı mücadele kadar önem verdikleri hususun, etkili eserler ve yayınlar çıkarmak suretiyle olduğunu ve Türkiye'nin insanlık karşısında haksız olduğu için değil, hakkını korumak ve açıklamasına layık olduğu önemi vermeyi bilmemesi yüzünden böyle bir muameleye maruz kaldığını ${ }^{15}$ belirtmekteydi.

Her milletin medeniyet karşısında kazanmaya çalıştığı var olan mevkiini geliştirmek ve onaylatmak için milletlerarası faaliyetlere büyük önem vererek, en değerli konuşmacı ve uzmanlarını milletlerarası toplantılara gönderdiği ve onların da ortak amaca hizmet doğrultusunda kendi ülke menfaatlerini sağlamaya çalıştıklarını ifade eden Cemil Bey, Türkiye'nin bu toplantılara katılmaması ve ilgili kişilerle temas ve ilişkilerden doğacak faydadan mahrum kalmasına neden olduğu gibi, kendisini ilgilendiren ve görüşlerine yer verilmesi gereken meselelerin, Türkiye'nin bu toplantılarda yokluğu nedeniyle aleyhine ve Türkiye'nin doğrudan zarar görmesine sebep olacak şekilde sonuçlanmasına neden olduğunu ve yine insanlığın ortak amaçlarına hizmet etmek amacıyla bütün devletlerce düzenlenen bu toplantılara Türkiye'nin katılmamasının kayıtsızlık gösterdiği yolunda bir düşünce doğurduğunu bunun da milletlerarası mevkisinin sarsılmasına yol açtığını ${ }^{16}$ vurgulamaktaydi.

Yukarıda da bahsedildiği üzere, Türkiye'nin milletlerarası toplantılarda resmen bulunmaması veya yokluğu nedeniyle kendisini ilgilendiren ve görüşlerine yer verilmesi gereken birçok mesele, aleyhine sonuçlanmakta ve Türkiye doğrudan zarar görmekteydi. İşte Türkiye'nin bu nedenle milletlerarası toplantılara katılması gereğini ilk gören ve söyleyen Macarlar olmuşlar ve büyük bir iyilikseverlik örneği göstererek 1921 yılında Peşte Başşehbenderliği’ne başvurarak, "Cemiyet-i Akvam’a Müzaheret Cemiyetleri Beynelmilel İttihad”ına bir cemiyet teşkil ederek dahil

\footnotetext{
${ }^{15}$ Cemil, Cem'iyet-i Akvam'a Müzaheret Cem'iyeti..., s.4-5.

16 Mehmed Cemil-Menemenlizade Edhem, Cem'iyet-i Akvam'a Müzaheret Cem'iyeti'nin Beyne'l-milel..., s.3; Cemil, Cem'iyet-i Akvam'a Müzaheret Cem'iyeti, s.5-6.
} 
olunması lüzumunu tavsiye eden bir mektup göndermişlerdi. Ancak mektup İstanbul'a gelmemiş ve ne olduğuna dair bir bilgiye de ulaşılamamıştı.

“Cemiyet-i Akvam'a Müzaheret Cemiyetleri Beynelmilel İttihadı”nı 1921 yılında Cenevre'de yaptığı beşinci konferansı sırasında, bu faaliyet, Cenevre Sefiri Cevad Bey'in dikkatini çekmiş ve İstanbul'a bir mektup göndermişti. Cevad Bey, mektubunda Müzaheret Cemiyetleri İttihadı hakkında bilgi vermiş ve sonra şunları dile getirmişti:

"Cem'iyet ittihadının atide oynayacağı rolün ehemmiyeti derkâr ve bugünkü haliyle bile iştirak eden milletlere te'min eylediği menafi'i pek kesir olduğu cihette bu menafi'-i haliye ve müstakbele ihmal kılınmayarak bunlardan memleketimizin de müstefid edilmesi labüddür kana'at-1 hakiranesindeyim.

“Union'a (Birliğe) dahil olacak bir cem'iyet-i milliyemiz bulunursa orada cereyan edecek müzakeratta bizim de bir re'yimiz ve hususiyle memleketimiz hakkında söylenecek pek çok sözlerimiz ve yapılacak müdafa'alarımız bulunabilir ki, gerek bu cihetin ve gerekse murahhaslarımızın bu ictima'alar esnasında bütün 'alemin rical-i siyasiye ve 'ilmiyesiyle temasta bulunmaları keyfiyetinin vatan ve millet için son derecelerde mucib-i muhissenât olacağı bedihidir" ${ }^{17}$.

Cevad Bey'in bu mektubunun yanı sıra, 9-16 Ekim 1921 tarihleri arasında İtalya'nın Torn (Thorn) şehrinde toplanan ve şehrin adıyla anılan ilmi kongreye ${ }^{18}$ Türkiye'yi temsilen katılan Darülfûnun İdare Hukuk Müderrisi Muslihiddin Adil Bey'in kongre izlenimleriyle, bu katılımdan ülke adına görülen fayda ve Muslihiddin Adil Bey tarafından yazılan layiha, milli bir cemiyet teşkili hususuna da dikkat çekmişti. Bunun üzerine çoğunluğunu Darülfûnun müderrislerinin oluşturduğu girișimcilerin bir araya gelmesiyle Cemiyet-i Avkam'a Müzaheret Cemiyeti kurulmuş, nizamnamesi hazırlanarak, resmi ruhsatı alınmıştı. Resmi ruhsatın alınmasından sonra cemiyetin kurulușuna dair tüm bilgiler Türkçe ve Fransızca bastırılarak dağııılmıştı. Cemiyet milletlerarası sahada hemen faaliyete geçmek istediğinden gerekli iç düzenlemeyi ve bununla ilgili zorluğu gidermek için büyük bir çaba sarfetmişti ${ }^{19}$.

17 Mehmed Cemil-Menemenlizade Edhem, Cem'iyet-i Akvam'a Müzaheret Cem'iyeti'nin Beyne'l-milel..., s.4.

${ }^{18}$ İstanbul Darü'l-fünûn'unun resmen davet edildiği bu kongre, Thorn İçtimaiyat İlmi Encümeni'nin teşebbüsü ve İtalyan hükümetinin desteği ile toplanmıştı. I. Dünya Savaşı'ndan sonra Türkiye'nin davet aldığı ilk ilmi kongreydi. 22 devlete mensup 150 üyenin katıldığı bu kongrede, kongre programı beş kısımda tanzim edilmiş, birinci kısmın ilk önemli maddesini Cemiyet-i Akvam Antlaşması'nın tatbikinde gerekli görülen değişiklikler teşkil etmişti. (Muslihiddin Adil, Beyne'l-milel İçtima'iyat Kongresi ve İntiba'alarım, İstanbul, Matba'ai Amire, 1338-1341, s.4-7.).

19 Mehmed Cemil-Menemenlizade Edhem, Cem'iyet-i Akvam'a Müzaheret Cem'iyeti'nin Beyne'l-milel..., s.4. 
Türk Müzaheret Cemiyeti'nin Cemiyet-i Akvam'a Müzaheret Cemiyeti Milletlerarası Birliği'ne Kabul Başvurusu

Türkiye Müzaheret Cemiyeti çalışmalarını tamamladıktan sonra, Cemiyet-i Akvam'a Müzaheret Cemiyetlerinin oluşturduğu milletlerarası birliğe, Türk müzahir cemiyetinin kurulduğunu ve birliğe kabulüne dair bir telgrafı 1922 yılı Mayıs ayı ortalarında merkezi Brüksel'de bulunan birliğin umumi katipliğine gönderdi. Gelen cevapta, bu teşebbüsün samimiyetle alkışlanmakta olduğu, birliğe kabul meselesinin Haziran ayı başlarında Prag'da toplanacak kongrede ele alınacağ bildirildi $^{20}$. Bunun üzerine Türkiye Müzaheret Cemiyeti vakit geçirmeden Prag'a gidecek heyeti seçim işine girişti. Türkiye'yi Prag'da temsil edecek kişiler, Rıfat ve Hüseyin Hilmi Paşalarla, Cavid, Edhem, Mehmed Cemil ve Ahmed İhsan Beylerle, Prenses İffet ve Leyla Vahid Hanımlardan oluşmaktaydı. Ancak Türkiye Prag'da Ahmed İhsan, Edhem ve Mehmed Cemil Beyler tarafından temsil edilecek, diğerleri mazeretleri sebebiyle heyette yer alamayacaklards ${ }^{21}$.

Konferans Prag'da 4 Haziran 1922 Pazar günü açılacaktı. Türkiye'nin Cemiyet-i Akvam'a Müzaheret Cemiyetleri Beynelmilel İttihadı'na kabulü hususunun ilki birliğin idare heyeti, ikinci olarak meclisi, üçüncü olarak umumi heyeti tarafından görüşülüp karar vermesine bağlı olduğundan ve bu hususun ilki 3 Haziran Cumartesi sabahı, ikinci olarak meclisin, aynı gün akşam üzeri toplanıp, kabul meselesini inceleyeceğinden, Türk Müzaheret Heyeti'nin Cumartesi gününden önce Prag'a gelmesi gerekti. Mehmed Cemil Bey İstanbul'dan Edhem Bey Karlsbad'dan hareket ederek 1 Haziran 1922 Perşembe günü Prag'a ulaştılar. Ahmed İhsan Bey'in de ${ }^{22}$ Cumartesi akşam üzeri Prag'a varmasıyla heyet bir araya geldi ve heyetin başkanlığını da Edhem Bey üzerine aldı. ${ }^{23}$

\section{Türk Müzaheret Cemiyeti Delegeleri Prag’da}

1 Haziran 1922 Perşembe günü Prag'a gelen Edhem ve Cemil Beyler burada "Cemiyet-i Akvam'a Müzaheret Cemiyetleri Beynelmilel İttihadı" Umumi Katibi ve

${ }^{20}$ Vakit, 24 Mayis 1338/1922, No: 1600 .

${ }^{21}$ Mehmed Cemil-Menemenlizade Edhem, Cem'iyet-i Akvam'a Müzaheret Cem'iyeti'nin Beyne'l-milel..., s.5.

${ }^{22}$ Ahmed İhsan (Tokgöz) Bey, başta kendisi olmak üzere çıkardığı Servet-i Fünun adlı dergiyle Türk edebiyat tarihinde ve Türk basın hayatında iz bırakan önemli isimlerden b iridir. 1920-1924 yılları arasını Münih'te geçirmiştir. Buradayken Ankara'nın emriyle faaliyet sahası Almanya ve Avusturya olmak üzere Ankara Matbuat ve İstihbarat Şubesi'ni açmıştır. TBMM Matbuat Umum Müdürlüğü'nün kendisine gönderilen milli hükümete ait haberleri Alman ve Avusturya basınına ulaştırarak, Milli Mücadele'ye önemli hizmetlerde bulunmuştur. (Mücellidoğlu Ali Çetinkaya, Son Asır Türk Tarihinin Önemli Olayları İle Birlikte Yeni Mülkiye ve Mülkiyeyiler Tarihi, Mülkiye Şeref Kitabı III.Cild, Ankara, 1968-1969, s.237; Bilge Ercilasun, Ahmet İhsan Tokgöz, T.C.Kültür Bakanlığı Yayınları, Ankara, 1996, s.27.). Ahmed İhsan Bey, 1922 yılında Münih'te olduğuna göre, buradan Prag'a hareket etmiş olsa gerektir.

${ }^{23}$ Mehmed Cemil-Menemenlizade Edhem, Cem'iyet-i Akvam'a Müzaheret Cem'iyeti'nin Beyne'l-milel..., s.4-6. 
Borda Darü'l-fünûn müderrislerinden Rovisen'le görüşerek Türk Müzaheret Cemiyeti'nin kurulmasının amacı ve kurucuları hakkında bilgi vermiş ve Türkiye ile ilgili meselelerin genelde çok yanlış anlayışlara göre düşünülmüş esasları hakkında kendisi aydınlatılmıştı.

3 Haziran Cumartesi sabahı toplanan idari heyet Türk Müzaheret Cemiyeti'nin birliğe kabulü lehinde karar vermişti. Ancak aynı hususu görüşecek olan meclis, birçok meseleyi incelemek durumunda olduğundan, bütün kabuller bu işle meşgul olacak komisyona havale edilmiş ve Türk heyeti de durumu Cumartesi akşamı öğrenmişti.

Bütün kabuller ve nizamnâmenin değiştirilmesine dair hususlar birinci yani dahili komisyona aitti. Komisyonun riyasetine Belçika Ayan'ından ve Cemiyet-i Akvam heyetinin tanınmış üyelerinden Lafonten, mazbata katibliğine Yunanistan Müzahir Cemiyeti Katibi ve Atina Darü'l-fünûn'u Devletler Hukuku Müderrisi Seferiyadis ve katipliğine de Macar heyetinden Vander Handere seçilmişti.

\section{Prag Konferansı}

Dahili Komisyon Pazar günü saat üçte toplandı. Belçikalıların Türkiye aleyhinde bir öneriyi Cemiyet-i Akvam'da dile getirdikleri gibi Yunanlılar da Türkiye'nin birliğe kabul edilmemesi yolunda her vasıtaya başvurmakta idi. Hatta Yunanlılar isim ve şöhretinden medet umdukları Venizelos'u idare heyetine dahil etmeye çalıştılar. Bu nedenle Türk Müzaheret Cemiyeti'nin milletlerarası birliğe kabulü meselesinde bir hayli zorlukla karşılaşacağı anlaşılmaktaydı. Gerçekten Türk heyetinin bir Macar delegesinin daveti üzerine dinleyici sıfatıyla katıldığı bu komisyonda iki saat süren şiddetli tartışma ve konuşmalar bunu açık bir şekilde göstermişti ${ }^{24}$.

Birliğin Umumi Katibi Rovisen, komisyonda kabul meseleleri hususunda yaptığ konuşmada kabul talebinde bulunan Bulgaristan, Ermenistan vs. müzahir cemiyetlerinin hepsine Türk heyetini takdim edip, Türkiye'nin birliğe kabulünün büyük önem ve yararına değinerek, kayıtsız ve itirazsız kabulüne oy verilmesini istedi. Bunun üzerine raportör olmak itibariyle ilk sözü alan Yunan delegesi Seferiyadis Rovisen'in sözlerine katılamayacağını belirterek niyetini açıklamaya başladı. "Cihanın ekseriyetle ve hatta umumiyetle bizi tanımayan muhitlerde efkâr-1 'ammeyi 'aleyhimize tehyic için husemamızın bir 'asırdır Mösyö Seferiyadis yine bu silaha, bu ta'n ve ithama müraca'at etti. Bir 'ilim ve hukuk adamına şeref vermeyen ve teşhis ettiği milletin de menafi'ine muvaffakatı cay-1 şüphe olan bir eda-yı mübalağa ile mezalimden, fecayi'iden, katli'amlardan, tehcirlerden hunharlıktan, yağmagirlikten, haremlerde yaşayan esir ma'sum Hıristiyan kızlarından bahsetti. Bir milyon Ermeni kesmişiz! Bugün de cihan-1 medeniyet Anadolu'da 400 bin Rum'un şahid-i efnası oluyormuş! Ne çocuk, ne kadın, ne ihtiyar hiç kimseye aman verilmiyormuş! Türk boyunduruğundan reha bulunan

${ }^{24}$ Mehmed Cemil-Menemenlizade Edhem, Cem'iyet-i Akvam'a Müzaheret Cem'iyeti'nin Beyne'l-milel..., s.5-6. 
milletler bugünkü necat ve istiklale kaç 'asırlık ne vicdan-1 şikâf mezalimi iktiham ederek, ne kanlı fedakarlıklar bahasına nail olabilmişler! Böyle kanlı bir memleketin cem'iyetini böyle 'ulvi emellerle müteşekkil bir hey'ete kabul etmek ve onlara el vermek ittihad hey'etinin ta'kib ettiği insani mefkurelerle kabil-i te'lif olamayacağından reddimizi talep etti ve şayed kabul edilirsek kendisi üç senedir hadimlerinden olduğu bu hey'ette kalamayacağından ona göre iki cihetten birinin tercihini teklif eyledi",25.

Seferiyadis'in Türkiye aleyhinde sarfettiği bu ağır ve dayanaktan yoksun iddialara karşı orada "asırlardan beri taht-1 idaremizde kalmış yerlerde bugün bizi istihlaf eden ve idare-i Osmaniye'nin iddi'a olunduğu gibi katl ve efna değil, bir amiziș ve 'anasırı muhafaza esasına istinâd ettiği kendilerine hatırlatılan devletler mümessilleri vardı." 26 Yine Türkiye için itham sebebi sayılacak meseleler karşısında Yunanistan'ı sorumlu tutmak gereken ağır olaylar meydana geldiğini bilenler veya bu hususta aydınlatılan temsilcilerle, Türkiye'nin bu cemiyetler birliğine girmesinde genel ve özel şekilde ilgilenen, bunda fayda gören heyetler vardı. Bu suretle Seferiyadis'in Türkiye'ye yönelttiği ağır itham ve iddiaları içeren konuşması çok aşırı bulunarak cemiyet temsilcileri üzerinde etkisini kaybettirdi. Önce Macaristan delegelerinden Komisyon Katibi Vander Handere, İtalya heyetinden genç bir yazar, Fransız Müzahir Cemiyeti Reisi vekillerinden ki sonra cidden bir Türk dostu olduğunu kanıtlayan Koffer, Fransa Mebusan Meclisi'nin tanınmış üyesi ve Fransız Müzaheret Cemiyetler Birliği Reis vekillerinden Henessi ve son olarak İngiliz delegesi Albay David Davis “Cemiyet-i Akvam'a Müzaheret Cemiyetleri Beynelmilel İttihadı”na Türkiye'nin kabulü lehinde bir konuşma yaptılar. Bu konuşmada Türkiye'de meydana gelen olaylardan sorumlu tutulması ve bu nedenle cemiyete kabul edilmemesinin haksızlık olacağı, aksine birliğin hizmet ettiği insani fikirlerin Türkiye'de de yayılması için birliğe kabul edilmesi gerektiği belirtilmekteydi. Fransız Koffer bu esas yönden de çok ileri giderek, savaş ve facia propagandasının siyasi bir amaçla çıkarıldığını sözlerine ekledi.

Türkiye lehine gelişen bu durumdan sonra Umumi Katib Prof. Rovisen, Anadolu'daki azınlıklar meselesinin diğer bir komisyonun müzakere programına dahil olduğundan bahisle, mezalim meselesinin orada inceleneceğini ve bu komisyonun işi olmadığını, bu komisyonda incelenecek hususun, cemiyetin usulen kurulup kurulmadığı ve bu itibarla Türk Müzahir Cemiyeti aleyhinde bir itiraz bulunup bulunmadığından ibaret olduğunu ifade etti. Prof. Rovisen, cemiyette nizami ve şekli bir eksik olmadığı gibi, Seferiyadis'in de bütün itirazları arasında da cemiyeti kuranlar ve buraya gönderilenler hakkında bir şey söylememesinin bu yönde bir itirazı bulunmadığı şeklinde anlaşıldığını belirterek Türkiye'nin birliğe kabulüne oy verilmesini önerdi. Bu sırada nefes nefese komisyona giren ve özellikle çağrıldığı anlaşılan Eski Sırp Hariciye Nazırlarından Zoçuvig hemen söz olarak Türkiye'nin kanun dışı addedilmesini böyle bir heyette zaruri bir yerinin

${ }^{25}$ Mehmed Cemil-Menemenlizade Edhem, Cem'iyet-i Akvam'a Müzaheret Cem'iyeti'nin Beyne'l-milel..., s.7.

${ }^{26}$ Mehmed Cemil-Menemenlizade Edhem, Cem'iyet-i Akvam'a Müzaheret Cem'iyeti'nin Beyne'l-milel..., s.7-8. 
olmayacağını belirtti. Zoçivig'in amacı sadece Türkiye'yi değil, Bulgaristan heyetini de birliğe kabul ettirmemektii ${ }^{27}$.

Yine bu sırada komisyona gelen Prof. Mersiye ${ }^{28}$ yapılan ithamlara yüksek bir ifade, parlak bir üslûp ve büyüleyen bir konuşma tarzıyla karşılık vererek, Anadolu'da sürüp giden mezalim ve yok etme efsanesinin vicdanları ayaklandırmak için ortaya çıkarıldığını, Türklüğün kötü fiiller işlemediği ve bu yönde temiz olduğunu aslında bu heyetin inceleme hükmüyle bir hakim vaziyeti takınmaya yetkisi olmadığını ifade ettikten sonra, bir İslam heyetinin birliğe katılma talebinin reddinin bütün dünyada ve İslam aleminde meydana getireceği etkinin önemini vurguladi.

Prof. Mersiye'den sonra tekrar söz alan Seferiyadis, kendisinin çekilmemesi için arkadaşları tarafından yapılan beyanlara teşekkür ettikten sonra (Seferiyadis bir önceki konuşmasında Türkiye'nin birliğe kabulü halinde kendisinin geri çekileceğini bildirmiş ancak Türkiye aleyhinde yaptığı konuşmada ă̆ır itham ve iddialarda bulunması tepki çekmiş ve kendisi çok ileri giderek hata yaptığını anlamıştı) anası, babası öldürülmüş, 25 sene Türkiye'de düşünülemeyecek facialar görmüş bir adam olması itibariyle hissiyatına yenilmiş olarak ileri gitmişse mazur görülmesini, Türklerin birliğe kabulünün Türkiye'de büyük Rum azınlığı bulunması dolayısıyla ileride bizzat kendilerinin önereceklerini, fakat Türk cemiyetinin hem yapılan mezalime karşı ne şekilde hareket etmiş olduğunun incelenmesini hem de bir sene çalışarak kabul edilmeye fiilen layık olduğunu isbat edebilmesi için Türkiye'nin cemiyete kabulünün bir sene ertelenmesini önerdi ve bu arada Seferiyadis'in Türklere karşı bir çeşit sevgi duyduğunu bunun sebebinin çoğunlukla Türklerin kanında Yunan ve Hıristiyan kanı bulunduğunu söyleyecek kadar ileri gittiği(!) görüldü ${ }^{29}$. Yunanlılara atfedilen facia meselesini şiddetle reddederek eğer Yunanlılardan bu yolda meydana gelmiş bir hareket varsa kendisinin heyette yerini koruyamayacağını söyleyecek kadar hissiyatına yenilen Seferiyadis Fransızlara da iki sene önce Almanların birliğe kabul edilmemesi yönünde takınmış oldukları tavrı hatırlatarak, Almanların Türkler gibi tehcirler, zulümler, öldürmeler yapmadıkları bu nedenle kıyas olunamayacağını söyleyip, onlar hakkında da böyle yapılmadı mı? demek isterken Fransız Mebusu Henessi'den aldığı cevapla adeta azarlandı. Durum aynı durum değildir sözlerinin çeşitli sıralardan duyulması üzerine büsbütün asabileşen Seferiyadis söylemeye hakkım yok mu? Öyle değil miydi? derken artık onu kimse dinlemiyordu.

${ }^{27}$ Mehmed Cemil-Menemenlizade Edhem, Cem'iyet-i Akvam'a Müzaheret Cem'iyeti'nin Beyne'l-milel..., s.8-9; Cemil, Cem'iyet-i Akvam'a Müzaheret Cem'iyeti, s.10-11.

${ }^{28}$ Profesör Mersiye (Mercier) : Lozan Hukuk Fakültesi ve Paris Milletlerarası Devletler Hukuku Okulu'nda Devletler Ceza Hukuku Profesörü

${ }^{29}$ Mehmed Cemil-Menemenlizade Edhem, Cem'iyet-i Akvam'a Müzaheret Cem'iyeti'nin Beyne'l-milel..., s.9; Cemil, Cem'iyet-i Akvam'a Müzaheret Cem'iyeti, s.11-12. 
Yugoslavya delegesinin Seferiyadis'e arka çıkan konuşmasından sonra Türkiye'nin birliğe kabul edilip edilmemesi hususu oya sunuldu. Önce ertelenmesi veya kabulü yönünde oylama yapıldı. Bu oylamada, İngiltere, Fransa, İtalya, Polonya, İsviçre ve Macaristan kabul yönünde, Yunanistan, Japonya, Yugoslavya, Çekoslovakya, Romanya ve Belçika ertelenmesi yönünde oy kullandı. Bundan sonra kabul ve red yönünde oylamaya geçildi. Bu oylamanın sonucunda da Türkiye'nin birliğe kabulüne beş ülke olumlu oy verirken, dört ülke reddetti, üç ülke de çekimser kaldı. İlk oylamada kabul yönünde görüşünü ortaya koyan Polonya son yapılan oylamada bu görüşünü değiştirmişti ${ }^{30}$.

Böylece Türkiye, komisyonda birliğe kabul yönünde beş oy olarak ilk kapıyı aralamış oluyordu. Bu aşamadan sonra Türkiye'nin kabul meselesi Umumi Heyet Toplantısı'nda da ele alınacaktı. Ertesi gün Umumi heyet saat üçte toplandı.

Toplantıda, komisyonda ilk önce Türkiye'nin kabul meselesi oylandığından burada da yine Türkiye'ye öncelik verilmesi gerekirdi. Ancak komisyonun mazbata katibi sıfatıyla Umumi heyette de başkanın yanında oturan Yunan delegesi Seferiyadis, söze önce Türkiye'den başlamakla beraber araya Ermenistan'ı sokarak kabulünü önerdi. Umumi heyet bu öneriyi itirazsız kabul etti. Seferiyadis'in böyle bir hareketten iki türlü amacı olabilirdi. Ya Ermenileri Türkiye aleyhinde söz söyletmek ya da Türkiye aleyhinde oylarını sağlamaktı. Durumu anlayan Türk heyeti hemen harekete geçerek icap edenleri aydınlattı.

Seferiyadis'in konuşmasını tamamlamasının ardından bir diğer Yunanlı Antonyadis söz aldı. Konuşması Seferiyadis gibi yine birçok mezalim efsanesiyle dolu idi. Mezalimi araştırmak için Anadolu'ya bir heyet gönderilmesi kararlaştırıldığı bir sırada Türk Cemiyeti’nin birliğe kabulünün bu kararla birbirine zıt düşeceğini açıklayarak, araştırma sonucunun beklenmesini ve Türkiye'nin kabulü meselesinin gelecek seneye ertelenmesini önerdi. Antonyadis'in konuşmasında dikkati çeken önemli bir nokta Seferiyadis'in 400 bine çıkardığı savaş kayıplarını 600 bine yükselterek göstermiş olmasıydı. Türk heyeti Fransa'nın Sarı Kitabı'na dayanarak yazılmış olan ve delil olarak sunduğu Türkiye haritalarını bu sırada orada bulunanlara vermiş, elden ele dolaşan haritalarda gösterilen rakamlar sadece mahir bir ifadeyle itham edilen olayda değil, genel sayı itibariyle de ne derece gerçek dişı olduğu hakkında bir fikir vermekteydi ${ }^{31}$.

Antonyadis'ten sonra Prof. Mersiye söz alarak, tahkikat heyetinin sadece Anadolu'ya değil, Yunan ordusunun işgali altında bulunan yerlere de gönderilmesinin teklif edildiğini beyan etti ve bunu Antonyadis'e de tasdik ettirerek onu heyet huzurunda küçülttükten sonra Türkiye'nin kabulünün bu araştırmanın

30 Mehmed Cemil-Menemenlizade Edhem, Cem'iyet-i Akvam'a Müzaheret Cem'iyeti'nin Beyne'l-milel..., s.9-10; Cemil, Cem'iyet-i Akvam'a Müzaheret Cem'iyeti, s.12.

${ }^{31}$ Mehmed Cemil-Menemenlizade Edhem, Cem'iyet-i Akvam'a Müzaheret Cem'iyeti'nin Beyne'l-milel..., s.10-11; Cemil, Cem'iyet-i Akvam'a Müzaheret Cem'iyeti, s.12-13. 
lüzumsuz olduğu zannını dolaylı olarak gösterebilirse, reddinin de sorumluluğu gerektiren bir durum olduğunun anlaşılacağını, halbuki böyle bir ihtimalin söz konusu edilemeyeceğini belirtti. Prof. Mersiye'nin bütün birlik heyeti üzerinde büyük bir nüfuzu olduğu gibi, muhakeme ve söz söyleme sanatının da muhalifleri üzerinde kıyaslanmayacak bir etkisi vardı. Söyledikçe alkışlanan Mersiye sonunda İslam dünyasının öneminden bahsederek Türkiye'nin kabul edilmemesi veya kabulünün ertelenmesi sonucunda adeta heyeti korkutacak beyanatta bulundu.

Prof.Mersiye'nin bu konuşmasından sonra bile hala ümidini kesmeyen Seferiyadis, Türk Müzaheret Cemiyeti'nin nizamnamesini eline alarak asabi ve yüksek bir ifadeyle cemiyetin dahili faaliyetinde yer alan üçüncü madde hükümlerini cümle cümle okumaya başladı. Bu maddenin diğer nizamnamelere uygun düşmediğini, İslam ahali, milli saltanat, devletler hukukuna aykırı anlaşmalar tabirleri üzerinde bilhassa durarak bunların kendi zihninde yer ettiği düşüncelere göre anlamını açıkladı. Özellikle barış antlaşmalarının siyasi içeriğini takip eden bir heyete karşı, bunlar işlerine gelmeyen anlaşmalar ve barış antlaşmalarını devletler hukukuna aykırı addederek, şimdiden icra etmemeye hazırlanıyorlar hükmünü çıkararak, nizamnamenin düzeltilmesi ve değiştirilmesi için gelecek seneye ertelenmesini istedi ${ }^{32}$. Fakat Türk heyeti bu itirazlara hedef olabilme durumunu önceden düşündüğünden ve açıklamasını yaptığından, itirazların büyük bir etkisi olmadı. Hemen oylamaya başvuruldu. Bu sırada Ermenistan'ın görüşü soruldu ancak henüz kabulüne oy verilmiş bir heyetin bu yönde görüş hakkını sunamayacağı, Türklerden sonra komisyona kabulü kararlaştırılmış bir heyet olduğuna dair Fransızlar başkana şiddetli bir uyarıda bulundular. Bunun üzerine Ermenilerin görüş bildirmeye hakkı olup olmadığ 1 oylamaya sunuldu ve hakkı olmadığı umumi heyet tarafından kabul edildikten sonra Türk Müzaheret Cemiyeti'nin birliğe kabulü veya gelecek seneye ertelenmesi hususu için oylamaya geçildi. 54 oyla birliğe kabul edilen Türkiye'ye kabul yönünde oy veren ülkeler, Almanya, Avusturya, Çin, Fransa, İngiltere, Macaristan, Japonya, İtalya, Hollanda, İsveç ve İsviçre idi. Yalnız İsviçre'den dört oy kabul, bir oy red şeklinde verilmişti. Otuz küsur oy kabulün ertelenmesi yönünde çıkarken altı oy da çekimser olarak kullanılmıştı.

Yunan heyetinin Türkiye aleyhinde sarfettiği tüm çaba ve mesai böylece sonuçsuz kalırken, gerçekler ve insanlık huzurunda yenilen Yunanlılar, toplantının yapıldığı muazzam salonun yüksek kubbesi altında Türkiye'nin birliğe kabulü tebliğine, şiddetli ve sürekli alkışlar arasında şahit olmuşlar, Türklüğün ve hakkın fikri zaferinin nasıl tebrik edildiğini görmüşlerdi.

Türk Müzaheret Cemiyeti'nin Cemiyet-i Akvam'a Müzaheret Cemiyeti Milletlerarası Birliği'ne Kabulü ve Prag Konferansı'nın Sonuçları

Türk heyeti kabulün hemen ardından yüksek sesle söz istedi ancak kabul meselelerinin bitiminden sonraya kalan söz hakkı bu meseleler uzadığı ve vakit

32 Mehmed Cemil-Menemenlizade Edhem, Cem'iyet-i Akvam'a Müzaheret Cem'iyeti'nin Beyne'l-milel..., s.11-12; Cemil, Cem'iyet-i Akvam'a Müzaheret Cem'iyeti, s.13-14. 
olmadığı nedeniyle başkan tarafından Türk heyetine sadece teşekkür için söz söylenmesine müsaade edebileceğini bildirdi. Bunun üzerine Türk Müzaheret Heyeti Başkanı Edhem Bey ayağa kalkarak, "O halde heyet-i muhteremeye teşekkür ederim ve söz hakkımı muhafaza ederim” dedi ve pekala cevabını aldıktan sonra toplantı sona erdi ${ }^{33}$.

Bundan sonra Türk heyeti, komisyonların ve genel oturumların müzakerelerine muntazam olarak katıldı. Bu oturumlardan en önemlisi Türkiye'yi en çok ilgilendiren konulardan biri olan azınlıklar meselesinin ele alındığı komisyon toplantısıydı. Komisyon Başkanı Dikinson tarafından yazılan ve azınlıklar komisyonunca kabul ve komisyona mal edilen kararların dokuzuncusu Türkiye'ye aitti.

Konferansa kabulü teklif edilen bu karar, azınlıklar hakkındaki antlaşmaların uygulanacağı sahanın Ermenistan, Türkiye, Anadolu vs. ihtiva etmekte olduğu, bu itibarla azınlıklar hukuku Cemiyet-i Akvam'ın garantisinde bulunduğundan cemiyetin bütün icra vasıtalarını bu ülkelerin azınlıklarını yeni savaşlardan veya kötü muamelelerden kurtarmak için derhal harekete geçirmenin Cemiyet-i Akvam'da temsil edilen devletlere ait olduğu ve "Cemiyet-i Akvam Müzaheret Cemiyetler İttihadı Meclis-i Akvam" üyesi bulunan devletlerden her birine bu çerçevede hareket etmek için başvurmayı görev saydığı şeklindeydi.

Azınlıklar komisyonunun Münih toplantısında Türkiye'den kimse bulunmadığı için Yunanlı delege Seferiyadis'in açıklamaları üzerine bu komisyon Türkiye aleyhinde bir kararı kabul ederek Cemiyet-i Akvam'a ve Sefirler Meclisi'ne bunu bildirmişti. Azınlıklar raporunun Türkiye'ye aid hükümleri de bu etki altında yazılmış olduğundan Türk heyetinin bulunduğu komisyonda Yunan delegeleri tekrar aynı konuyu gündeme getirdiler. Eski kararı genelleştirmek ve kabul ettirmek için uzun açıklamalarda bulunmak istemeleri ve bu hususta acele etmeleri üzerine Türk Heyeti Başkanı Edhem Bey söz alarak şunları söyledi:

"Yunan murahhasının bütün ithamatı ihtilal komitesinin raporundan veya rical-i hükümetin beyanatından başka bir şeye müstenid değildir. Şaibe-i tarafgiriden beri olamaması tabi'i olan bu beyanat, zannetmem ki, bu hey'etin vicdanını tatmin edebilecek bir mahiyeti haiz olsun. Herkes bilir ki mahalinde icra-yı tedkikat için bitaraf komisyonlar i'zamı teklif edildi. Bizi ancak bu kabil tedkikat netaicidir ki mes'uliyetlerin hakkıyla ta'yin ve tesbitine salih bir fikr-i salime isal edebilecektir. $\mathrm{Bu}$ ithamat burada gayr-1 meşru' bir maksadla ileri sürülmüş isnadattan başka bir şey değildir.

"Diğer taraftan Yunan murahhasları dünden beri müte'addid def'alar tekrar ettiler ki Anadolu'ya temeddüdünü bir vazife ile gelmişlerdir ve harabi değil refah ve sa'adet getirmişlerdir. Dünden beri diyorum çünkü biz ancak dünden beri duyuyoruz. Belki onlar iki seneden beri bunları mütemadiyen söylüyorlar. Ben size

${ }^{33}$ Mehmed Cemil-Menemenlizade Edhem, Cem'iyet-i Akvam'a Müzaheret Cem'iyeti'nin Beyne'l-milel.., s.12-13; Cemil, Cem'iyet-i Akvam'a Müzaheret Cem'iyeti, s.14. 
bunların yaptıkları cinayatı mübeyyin resmi ve kat'iü'l-mûfâd pek çok raporlar takdim edebilirim. Bunlar na'kabil red ve i'tiraz bir mahiyette olmakla beraber bitarafane bir surette te'sis-i kana'at etmek isteyen vicdanlarınıza böyle yek cihet bir vesika 'arzetmeyeceğim. Hatta I'tilaf Devletleri komisyonlarının barbar Yunan kabailinin yapmaya ehil oldukları tahribatı mahalen tevsik eden raporlarını da nakletmeyeceğim. Size Beyne'l-milel Salib-i Ahmer Anadolu Tahkik Hey'eti'nin, Salib-i Ahmer Risalesi'nin Mayıs 1921 tarihli nüshasında münderic raporundan yalnız birkaç satır okuyacağım. "Hey'et şu kana'ate vasıl olmuştur ki Yunan işgal ordusu iki aydan beri şibih-i cezirede İslam ahalinin mahvını ta'kib eylemektedir. Mertebe-i sübuta vasıl olan ahval-köylerin ihrakı, katli'amlar, ahalinin terhibi, tarihlerin ve mahallerin tevafuku- bu babda hiçbir şüpheye mahal bırakmamaktadır. Kendilerini veya izlerini gördüğümüz fecayi' müsellah çeteler ve kuva-yı muntazama-i Yunaniye tarafından ika' edilmiştir. Bu gibi fenalıklardan hiçbirinin Yunan Ordusu tarafından men' veya tecziye edilmiş olduğuna muttali' olmadık. Çeteler silahları alınarak dağıtılacaklarına hareketlerinde mazhar-1 mu'avenet oluyorlar ve kuva-yı muntazama-i askeriye ile el ele çalışıyorlar..."*

“Hanımlar ve Efendiler bu rapor mutala'at ve isnadad ihtiva etmiyor. O halde rica ederim Yunan delegesine sorunuz ki, Yunan ordusu hakkında hey'et-i muhteremeniz huzurunda öğünerek söyleyip durduğu fikri muhafaza ediyor mu?" Edhem Bey'in bu ifadesi komisyonda bulunanlar tarafından devamlı surette alkışlandı ${ }^{34}$.

Bu sırada Sırp delegesinin Yunanistan'ı desteklemesiyle ortaya çıkan ve heyet üzerinde kötü bir etki bırakan bazı itirazlar üzerine Ahmed İhsan Bey söz alarak, Anadolu'da bu kadar mezalim yaptığı kanıtlanmış olan bir ordunun hala medeniyet görevi yaptığından bahsedilmesine tahammül edilemeyeceğini açık bir surette ifade etti ve alkışlandı. Komisyon Başkanı Hollanda mebuslarından Rotkeres, Ahmed İhsan Bey'e söz verirken iki dakikadan fazla konuşmasına izin vermeyeceğini beyan etmişti. Ancak Yunan delegesine yarım saat konuşma izni verildiğinden Ahmed İhsan Bey bu hareketi doğal olarak protesto etmiş ve komisyon kararıyla kendisine on dakika konuşma hakkı verilmişti. Ahmed İhsan Bey sözlerini tamamladıktan sonra heyet başkanı Edhem Bey, tekrar söz olarak, Türk yurdunun en mamur ve en verimli kısımlarında Yunan ordusu tarafından yapılan katliam ve yağmalara bir son verilmesini isteyerek, tek emelinin kendi milli topraklarında yaşamaktan ibaret olan Türk ahaliyi mahv ve perişan eden ve bu cinayetlerden hiç bahsetmeyen komisyon

*Edhem Bey'in okuduğu bu rapor, Yalova, İzmit, Gemlik ve çevre köylerinde Yunanlılar tarafından Türk-İslam ahaliye karşı yapılan mezalimi araştırmak üzere Milletlerarası Araştırma Komisyonu'nda Cenevre Milletlerarası Kızılhaç delegesi olarak bulunan Morris Gehri'nin 12-22 Mayıs 1921 tarihleri arasını kapsayan araştırma raporudur. Bu raporun Revue International de la Croix-Rouge, C.III, No:31, 15 Temmuz 1921 sayısından Cenevre'de yapılmış ayrı basımı mevcuttur (Prof.Justin McCarthy, Ölüm ve Sürgün "Death and Exile", Osmanlı Müslümanlarına Karşı Yürütülen Ulus Olarak Temizleme İșlemi, 1821-1922, Çev.Bilge Umar, 2.Baskı, İnkılâp Kitabevi, İstanbul, 1998, s.317.).

${ }^{34}$ Mehmed Cemil-Menemenlizade Edhem, Cem'iyet-i Akvam'a Müzaheret Cem'iyeti'nin Beyne'l-milel..., s.32-34. 
raporunu protesto etti. Bunun üzerine İngiliz delegeleri Yunan heyetinin yeni tekliflerinin reddedilmesini isteyerek kararda yer alan azınlıklar tabiri yerine "muzdarip ahali" tabirinin konulmasını önerdiler. Bu öneri Türk heyeti tarafından da uygun görülerek, Yunan delegelerinin görüşüne bile başvurulmadan komisyonca kabul edildi ${ }^{35}$.

Azınlıklar meselesi görüşülürken Prag Darü'l-fünûn müderrislerinden Müsteşrik Prof. Mozil, Türk heyetine, Rum ve Ermeni patrikhanelerinin Hıristiyanlardan görmediği imtiyaz ve saygıyı Türklerin gösterdiğini, azınlıklara en önce iyi muamele edenlerin yine Türkler olduğunu, zulüm ve taassubu doğuya Hıristiyanların getirdiğini, Yunanlıların bu üç senede Türklere üç yüz senede iftira edilen mezalimden daha fazla mezalim yaptıklarını, Türk Tarihinin şanlı ve şerefli sayfalarla dolu olduğunu ifade etmişti ${ }^{36}$.

Prag Konferansı programında yer alan Anadolu'daki azınlıklar konusu, konferansın ilgili komisyonunda müzakere edilmiş ve bu hususta komisyona arzedilen kapsamlı açıklamalarla bunun genel bir bakış açısından çözümüne doğru önemli bir adım atılmıştı.

Türk Heyeti Prag'da kaldığı bir hafta boyunca dünyanın isim yapmış ilim ve siyaset adamları ve uzmanlarıyla bir araya gelmiş, o zamana kadar Türklerin temsil edilmediği toplantılarda Türkiye ile ilgili meseleleri kendi telkinlerine göre işlemeyi ve Türkiye aleyhinde kararlar aldırmayı alışkanlık haline getiren düşmanlara doğrudan müdahale ederek, Türkiye hakkında asılsız iddia ve iftiraları kanıtlarıyla çürütmek ve gerçekleri kapsamlı olarak açıklamak fırsatı bulmuştu.

35 Mehmed Cemil-Menemenlizade Edhem, Cem'iyet-i Akvam'a Müzaheret Cem'iyeti'nin Beyne'l-milel..., s.34.

${ }_{36}$ Mehmed Cemil-Menemenlizade Edhem, Cem'iyet-i Akvam'a Müzaheret Cem'iyeti'nin Beyne'l-milel..., s.44. 